\title{
Flickering Presence: Theorizing Race and Racism in the Governmentality of Borders and Migration
}

\author{
DAVID MOFFETTE \\ University of Ottawa, Canada \\ WILLIAM WALTERS \\ Carleton University, Canada
}

\begin{abstract}
Analytics of biopolitics and government have proven to be powerful tools in a growing scholarship examining the bordering, surveillance, securitization and contestation of migratory processes. Yet the critical potential of such research is hampered by the rather limited ways it has managed to make sense of race and racism. While Foucault was insistent that governmentality should orient itself to the understanding of singularities, too often race appears, when treated at all, as a general phenomenon. This article makes two contributions aimed at addressing these shortcomings. First, we survey studies in the governmentality of migration and develop a typology of what we call framings of race - the ways that race appears, is mobilized, or haunts this scholarship. Second, we look to recent debates about race and racism in Science \& Technology Studies for useful theoretical innovations that might help us study border-and race-making as mutually constitutive processes.
\end{abstract}

KEYWORDS race; racism; governmentality; migration; topology; Science \& Technology Studies

\section{Introduction}

Genealogies and analytics of biopolitics and government have proven to be powerful tools in a growing scholarship examining bordering, surveillance, securitization and contestation at play in the struggles over migratory processes in Europe and North America (for overviews, see Fassin, 2011; Walters, 2015). Over the last two decades, an important number of scholars have deepened the conversation between the study of mobilities and migration and the Foucauldian analysis of government, the management of 
circulation and flows, and the biopolitics of population sketched out in Security, Territory, Population (Foucault, 2007) and later studies of governmentality (e.g., Dean, 1999; O’Malley, Weir \& Shearing, 1997; Rose, 1999; Walters, 2012). While we are largely sympathetic to the aims and outcomes of this conversation, in this article we draw attention to the rather marginal place questions of race and racism occupy within it.

The heterogeneous scholarship on the governmentality of migration and borders is constantly changing, and the most dynamic innovations currently center on "the problematic of migration and borders, along with the social mobilizations, interventions and concerns that have emerged around keywords such as 'border regimes,' 'border spectacle,' 'autonomy of migration,' or 'border as method"' (De Genova, Mezzadra \& Pickles, 2015, p. 59). In a recent contribution oriented to an inventory of certain keywords, De Genova, Mezzadra and Pickles (2015, p. 56) map out this new approach to migration. "What's new about migration and borders?" they ask. Their answer identifies an emergent epistemic community defined in part by its connections with migrant movements, struggles, and concerns. But it is also defined by a new understanding of borders. These are not seen as limits or lines that simply exclude, nor as withering away, as was predicted by early theories of globalization. Instead, by joining migration and borders together these studies draw attention to the tendency of borders to multiply. They highlight borders as tools of "governmentality and management"; not purely negative or repressive tools of sovereignty but "more open and complex ways in which borders react to diverse kinds of migrant subjectivities and thereby operate to produce differentiated access and "rights" (De Genova, Mezzadra $\&$ Pickles, 2015, p. 57). We concur with these authors that in bringing the question of borders into the heartland of the study of migration some novel perspectives and emphases are being pursued. These include the fostering of a much more acute sensibility towards the different territorializations and securitizations of migration; the differential play of inclusion and exclusion; the complex place of technologies of government in shaping and contouring migration spaces and experiences; and a more sophisticated account of the relationship among states, territories, populations, and migratory processes. Yet, we find that the critical potential of such research is hampered by the rather limited ways it has managed to make sense of race and racism.

In this article we ask: where and how do race and racism feature in these studies of migration and borders? Based on a preliminary and admittedly incomplete survey of this literature, our first point is that these themes and analytics are not as prominent or as central as one might expect. Xenophobic fears, extremist movements, racist attacks, the circulation of stereotypes, problematics of integration and marginality, and nativist rhetorics are all very much present in the literature (Fassin, 2011; Huysmans, 2006; Schinkel \& van Houdt, 2010), and yet many write of securitization and demonization with only a brief allusion to the racially coded discourses at play. Indeed, in many accounts race only operates in the background (Amin-Khan, 2012; 
Moffette \& Vadasaria, 2016). Discussions regarding differential mobilities, sovereign bans, regimes of detention and deportation, or risk profiling draw attention to operations of profiling, segmentation, partition, and the fostering and capitalization of anxiety (Bigo, 2002; Geiger \& Pécoud, 2013; Muller, 2009; Rumford, 2006). Yet the connections to racialization and the postcolonial are generally muted or presumed. Of course, there exists an extensive scholarship in critical race theory (CRT), postcolonial studies and the sociology of immigration that does, at times, engage with those topics and where race is central. But it is still marginal in the governmentality of borders and migration scholarship. Perhaps it is thought to be so obvious as to not require foregrounding? Or perhaps this reflects the fact that one of the main locations of borders and migration studies has been International Relations (IR), a discipline that has historically shown a blind spot for race and coloniality (Gruffydd Jones, 2008; Sabaratnam, 2011; Vitalis, 2015; Vucetic, 2015). Whatever the precise elements at play, they have meant that there has been only a limited engagement with race.

This article makes two contributions. In the first part of the article, we survey studies in the governmentality of migration and borders, and develop a typology of what we call framings of race - the ways that race appears, is mobilized, or haunts the governmentality of migration scholarship. This helps us clarify the different ways that scholars have tackled this issue and explore how conceptualizations of race may, in turn, transform our understanding of governmentality. If we are to develop better ways to center race in our analyses, it is important that we start by mapping out its place in this scholarship and identifying engaging lines of research that do accord dynamics of race and racialization a prominent place. Three framings are identified. First, we discuss works that rarely mention race despite being informed, or rather haunted, by it. We call this framing the absent presence of race. We then look at works that use the words "race" and "racialization" and, at times, conceptualize them, but where the specificities of the complex historical process that the suffix "-ization" refers to are often left unexplored. We call this framing racialization as a generic process. Here, the language of racialization seems to be used in lieu of an analysis of the context-specific processes whereby race is made, unmade, and remade. Finally, we analyze works that pay close attention to shifts and emergence and provide non-linear genealogical accounts of the changing material and discursive regimes of race historically. We call this third framing, for lack of a better term, the transformationalist approach.

Although the development of this typology is a useful exercise in its own right, we use it to identify other sources of inspiration that are epistemologically, theoretically and methodologically compatible with the assumptions of the governmentality of migration and borders scholarship, and can provide us with tools to write better accounts of race and racism. In the second part of the article, we thus look to recent debates in Science \& Technology Studies (STS) for useful theoretical innovations that might 
address some of these shortcomings. In particular we highlight the theme of topologies of race, and argue that it would be fruitful to start a conversation between studies of topology and the three framings we identify.

\section{Absent Presence of Race}

In some otherwise very good work on immigration governance, race and racism are surprisingly completely absent (e.g., Bourbeau, 2011). In most of the literature however, race makes infrequent appearances through notions such as racism and Islamophobia, or in passing among the other items of the inventory of discriminations based on race, gender, class and sexuality. Despite a very limited engagement with race, racialization, and racism, these notions do inform the analysis. Just like in the societies that are the objects of analysis, in this literature "race tends to be a shadowy and slippery object" (M'Charek, Schramm \& Skinner, 2014a, p. 462). It is for this reason that, borrowing from various scholars (Ahmed, 2003; Goldberg, 2009; M'Charek, Schramm \& Skinner, 2014a, 2014b; Wade, 2010), we refer to this framing as one featuring an absent presence of race.

Indeed, even when the objective is to critique surveillance and border technologies, many researchers' focus on risk categories, digital surveillance, and bordering practices ends up simultaneously assuming race and racism but moving it to the background. This is the case in much of the surveillance literature. If one takes as a representative sample of this scholarship the recent Routledge Handbook of Surveillance Studies, the trend is quite obvious throughout the book (Ball, Haggerty \& Lyon, 2012). ${ }^{1}$ Here, "race is not absent in a straightforward way. Instead it is masked, tacit, hidden and displaced" (Wade, 2010, p. 44). Indeed, some of the works in the governmentality of migration scholarship study bordering practices and surveillance technologies and even denounce discrimination without ever centering race in the analysis. While this scholarship critiques the alleged neutrality of technological smart borders, for instance, it provides accounts of the social sorting of surveillance and of the filtering of borders (e.g., Lyon, 2008) in ways that contribute to the broader social trend that sees "race disappears into the seams of sociality" (Goldberg, 2009, p. 157). In so doing, this scholarship unwittingly also leaves the normativity of whiteness intact (Browne, 2015; Kobayashi \& Peake, 2000; Pugliese, 2010). This is one of the limits that Browne tackles though her historicizing of the racialized nature of current biometric information technology. Re-centering the practice of slave branding as an early biometric technology and drawing on the concept of epidermalization (see Browne, 2010; Gilroy, 2001; Hall, 1996), she coined the argument that we should "come to think of the concept of digital epidermalization when we consider what happens when certain bodies are

\footnotetext{
${ }^{1}$ The chapters by Browne (2012) and by Sa'di (2012) are exceptions.
} 
rendered as digitized code, or at least when attempts are made to render some bodies as digitized code" (Browne, 2015, p.193). Through this move, she put race and Blackness, as they developed through the histories of the Atlantic slave trade, as central to any understanding of surveillance. Unfortunately, works like Browne's remain uncommon in surveillance studies.

This absent presence is also frequent in security studies, and of particular interest here, in the Foucauldian securitization of immigration literature. Scholars have developed tools to study the ways that certain issues are framed and governed as security threats through a variety of discursive and non-discursive practices, and provided very insightful critiques of the logics of securitization (e.g., Huysmans, 2006), but rarely do they make explicit the racial dimension of the grids of intelligibility that provide the grammar for this framing. As with surveillance studies, there exist exceptions here too, but despite critiques pointing to the lack of attention to race (Amin-Khan, 2012; Ibrahim, 2005; Moffette \& Vadasaria, 2016), it remains the norm in Foucauldian critical security studies as well.

While this absent presence often manifests in the scholarship in ways that echo this open secrecy (Sedgwick, 1993) of race in western societies, at times scholars appear to simultaneously downplay race and grasp its haunting presence. Bigo's (2002) description of a governmentality of unease contributing to the securitization of immigration is perhaps the best example. In this landmark publication, Bigo develops a Foucauldian perspective on securitization and shows how security professionals, politicians and the media target immigrants as a way to both incite and manage a generalized unease distributed across our risk society. He frames this securitizing process as "a transversal political technology, used as a mode of governmentality by diverse institutions to play with the unease, or to encourage it if it does not yet exist, so as to affirm their role as providers of protection and security" (Bigo, 2002, p. 65). Race is not mentioned here. Now one can only do so much in an article, and opening security studies to a Foucauldian analytics was Bigo's aim, not the conceptualization of race. And yet his account portrays a rampant unease that appears like an eerie fog, a fear of uncertainty and otherness that sticks to racialized others, in a manner similar to Ahmed's (2003) accounts of the affective politics of fear. It is almost as though Bigo is actually depicting this absent presence of race in society - we easily read this fear and unease in his account as one that is racialized - but then race also evaporates from his own text. Here again, the racial dimension of the structural unease and the grids of intelligibility that inform the governing of immigration is not centrally discussed.

\section{Racialization as a Generic Process}

The second framing that we identify makes use of the language of race and racialization to account for the differentiated ways that borders impact 
subjects, as well as for the racialized dimension of technologies and knowledges. This framing goes beyond listing race, gender, class and sexuality in passing as markers of social differentiation, and uses the language of racialization to account for the historical, processual and dynamic quality of race. This is an important contribution. And yet, the concept often appears as a generic term, used in lieu of a fuller analysis of the specific working of "race in the making" (Vukov, 2016, p. 83) in a particular social and historical context.

For instance, in an important contribution Basham and Vaughan-Williams (2013) make the point that while gender and race have featured increasingly in research on migrations, borders and differential mobilities, scholars have failed to explore questions of intersectionality. As they put it, "drawing on Sherene Razack's [2004] work, we emphasize how such apparatuses [of biopolitical security] go hand in hand with gendered and racialized categorisations such as 'dangerous' Muslim masculinities, 'imperilled' Muslim femininities and 'modern' civilised western subjectivities" (Basham \& Vaughan-Williams, 2013, p. 510). They are interested not just in how borders affect men and women "of varying racial backgrounds" differently but how "bordering practices are indeed made possible by certain operating logics that are always already both highly gendered and racialized, and are structured by economic conditions of (im)possibility" (p. 510). They examine "the work that particular assumptions about gender, race and class do in shaping the political possibility of norm and exception as part of a broader investigation into how some borders give rise to others" (p. 510).

We highlight this work because it represents one of the most sophisticated and systematic treatments of race understood as a structuring or conditioning logic in recent governmentality of migration scholarship. The point is crucial, as it registers the assumptions that attach to perceptions of migration and refugees, the differentiated reactions, and the policies that are justified in their name. Further, their point about intersectionality is important, and with regard to racialization shows an understanding of race as always already gendered and classed. Their account also provides a remedy to the homogenizing effect resulting from the overly broad depiction of migration and migrants in some of the autonomy of migration literature (Sharma, 2009). They join other authors who attempt to address some of the bias of floworiented Foucauldian readings of the governing of migration by providing accounts of the links between racialization and subjection, and of the struggles between movement and control as one to be studied through an analysis of raced, gendered, and classed embodied encounters (Scheel, 2013a, 2013b).

But we also see two important limits to these framings of racial difference as racialization. First, in some usages the idea of racialization becomes overly monolithic and insufficiently historicized. Indeed, while genealogies and other critical studies of race show that it can be otherwise (Barot \& Bird, 2001; Muri \& Solomos, 2004), the literature on the governmentality of 
migration often seems to presume an overarching play of practices and processes of differential valuation that serve to negatively code the actions and lives of some, while implicitly or explicitly upholding and affirming (usually) white subjectivities. There is sometimes insufficient attention to shifts, reversals or discontinuities in regime. There is also sometimes a bundling together of anti-Black racism, Islamophobia, anti-Semitism and their distinct manifestations in different places and times, when instead we need to account for a diversity of racisms with distinct genealogies. We need tools to study racializing processes in their plurality. This argument echoes Goldberg's (2009) reason for avoiding the term "racialization." In general, he says, it is unclear whether the term is used in a descriptive or a normative manner. He explains: "Quite often it is put to work simply to suggest raceinflected social situations, those informed or marked by racial characterization" (Goldberg, 2009, p. 67), and not to deepen the analysis. This is often the case in the scholarship that concerns us here: the contradictions and complexities of the historically- and context-specific processes of racialization are missing from the analysis. While Foucault is at times invoked for ideas of race, it is usually in reference to his reflections on state racism, which he sees as a dividing practice that makes some live and lets others die. While this concept might work for the racisms of colonial modernity, we suspect it needs to be rethought and not merely transposed onto the racial present. Or while colonialism is often invoked, there is little attention paid to the twists and turns, and in particular the effects that anticolonial struggles and postcoloniality have introduced into the field of racial difference. A more Foucauldian approach to race would, one might assume, take seriously the idea of a genealogy to consider how distinct racializing processes emerged through "manifold circuits of production and reproduction" (Dillon \& Lobo-Guerrero, 2008, p. 283). Perhaps here we should leave the Foucault of Security, Territory, Population (2007) and revisit the specific genealogy of race and racism in $17^{\text {th }}$ to $19^{\text {th }}$ century France developed in Society Must Be Defended (2003) to look not for answers, but for methodological inspiration (Jabri, 2007).

Second, notions of racialization used in the governmentality of migration literature are too often presented as one-sided and exterior to their subjects. Racialization is typically something negative that is being done to migrants and refugees. They are being racialized, cast negatively, demeaned, made abject. Despite an abundance of work by critical race theorists to draw from, rarely is race examined as a site of struggle or contradictory subjectivity; the possibility that race-in-the-making contains the active presence of its subjects is not sufficiently canvassed. What might this active presence look like? How would it register the production of race through contradictory processes and struggles? Here, we fully share the call made by Mezzadra, Reid and Samaddar (2013) for a more political reading of Foucault's relevance to the postcolonial present. They insist that it is not enough to explain how "postcolonial regimes have achieved the debasements of political 
subjectivity," and that we should also register how "peoples, in their subjection to governance, can and do resist, subvert, escape and defy the imposition of modes of governance" (Mezzadra, Reid \& Samaddar, 2013, p. 2).

To grasp that race is made and remade from all sides, as it were, and not just from above, one needs look no further than recent work on genomics, postgenomics and biological citizenship (Inda, 2014; Rose \& Novas, 2005). While the biological sciences are generally regarded as one of the foundations with which race thinking sought to ground its dystopian vision of social domination, studies of the sociopolitical entanglements of the new genetics point to new framings of race and identity directed towards a potentially more progressive end. Hence, in writing of the "genetic reinscription of race," Abu El-Haj (2007, p. 283) notes that while new genetics may well have exclusionary effects within the governance of population, this is not all it does:

After all, the political impetus for including race, for insisting on diversity in the conduct of postgenomic medicine, comes in large part from people who organize or identify as minorities (including physicians/researchers) and who demand the right to equal treatment: Medicine has met identity politics, and out of that meeting point novel practices of both race and medicine [...] have been borne. (El-Haj, 2007, p. 292).

Extrapolating from such work we might observe that racialization is frequently a process of excluding, demeaning and fostering hierarchies. But that should not occlude the fact that race is also produced and transformed out of the many ways in which such asymmetries are contested.

\section{Transformationalist Perspectives}

While racialization is sometimes invoked by recent scholarship on the governmentality of migration in rather generic ways, we can identify a third perspective where race is more fully historicized. We call this framing transformationalist (e.g., Balibar, 1991; De Genova, 2016; Duffield, 2006; Hansen \& Jonsson, 2011; Hindess, 2002; Korvensyrjä, 2017; Turner, 2015). The second approach discussed above is largely oriented towards the vital endeavour of exposing and criticizing racial hierarchies, inclusive exclusions, and power relations in conjunction with migration policies, politics, and security apparatuses. Sometimes it makes reference to deep structures of colonialism but often only in passing. Transformationalist approaches, by contrast, provide a longer historical perspective and foreground questions of shifts and emergence. As such, they might be considered closer to the ethos of genealogy since they insist on developing understanding of the singularity and complexity of the present. 
In an important and agenda-shaping set of essays, Balibar (1991) has done more than most to sketch the outlines of a transformationalist approach, revealing its potential for studies of race, migration and borders. Nowhere is this more so than in his framing of the question of neo-racism and racism without races. While it is over two decades since this book appeared, some of its key arguments are worth revisiting in the context of migration and borders debates. Balibar (1991) juxtaposes biology-based and culturalist types of racism. According to him, the latter became a hegemonic form in western Europe in the post-war years following the discrediting of the former amidst the ruins of the Nazi project. In a series of points elaborating this shift, Balibar illustrates the value of historicization. He claims that cultural racism is a racism "of the era of 'decolonization,' of the reversal of population movements between the old colonies and the old metropolises, and the division of humanity within a single political space" (Balibar, 1991, p. 21). Or, as Duffield $(2006$, p. 71) puts it, we have gone from a racism of "biological-types in location" to a problematic of "cultural-types in circulation." This is important because the governmentality of migration literature has come to treat as second nature the fact that migration appears in dominant discourses as a human flow from "over there" to "here," and what these points underscore is how European racism is so bound up with a complex of im-migration that immigration has for some time functioned as a "substitute for the notion of race" (Balibar 1991, p. 20; also see De Genova, 2016, p. 80). Yet, this complex has perhaps only existed for some 70 years or so, and culture-based racism has never completely erased biological framings and foundings (M'Charek, Schramm \& Skinner, 2014a; Wade, 2010).

The perspective on shifts and types which transformationalism offers is important not just for specifying different racisms and their social and geopolitical context. This approach is also important because it theorizes how former racisms, as well as the policies formulated to govern those racisms, are still a part of our present. As Mezzadra and Rahola (2006, n.p.) put it, this relationship of immanence is manifest in a particular experience of time:

Postcolonial time is that in which colonial experience appears, simultaneously, to be consigned to the past and, precisely due to the modalities with which its 'overcoming' comes about, to be installed at the center of contemporary social existence - with the entire burden of domination, but also the capacity for insubordination, that distinguishes this experience.

This is reflected in what Balibar (1991, p. 21), borrowing from Taguieff (1986), calls "turn-about effects," but we might also call such discursive moves reversals or inversions. For example, the way that multiculturalism today is blamed for fostering communities that live apart, which creates - as the story goes - breeding grounds of alienation and, most alarmingly, radicalization. In other words, we have dominant discourses which implicate earlier formations of anti-racism in their explanations and justifications of 
contemporary forms of racialization. One is dealing with a multi-layered phenomenon in which past and present collide and interact.

Transformationalism is also important because it speaks to a problem we identified in many references to the racialization framing, namely the fact that they see race as constructed by dominant discourses and policies yet fail to acknowledge how struggles and histories are sedimented in those discourses. They plot racism on a straight line. Mezzadra and Rahola (2006, n.p.) warn of the danger

that in positing [...] a logic of absolute continuity we end up validating and perpetuating a "redemptive" mechanism, whether of self-absolution (in the case of the subaltern subject) or of mere removal (in the case of the "Western" subjects): removal, to the extent that it dispenses with anti-colonial struggles as a mere inconvenience $[\ldots]$ along the linear and uninterrupted thread of the history of domination and exploitation, as well as it deprives the insurgent colonial subject, the rebellious subaltern, of all possible forms of agency or of any possibility of directly intervening in history; self-absolution, to the extent that it eliminates from history all direct responsibility that is not identified with the colonial West and, so too, any revolutionary act that does not belong to the West, not only hands over all responsibility but also - and above all - shifts action from the colonised subject to the eternal (neo-)colonial Subject.

Although it is important to stress continuities with the past, we must temper such references with an openness to the new, and ask always how the emergent is shaped by struggles. In other words, we need genealogies that account for the "messy actualities" of racial governmentality (O'Malley, Weir \& Shearing, 1997, p. 504).

Finally, we insist one should not see transformationalism as providing a ready to use set of concepts, as though it were just a question of identifying other instances of cultural racism. In fact, it might well be that the described shift towards cultural racism was overblown and that, as M'Charek, Schramm and Skinner (2014a, p. 462) argue, "culture, culturalism, or cultural fundamentalism [...] has in any case not simply taken the place of racism grounded in nature [...] Rather, culture and religion come to be linked to biological differences and thereby gain a sense of duration and stability." More than the concepts themselves, it is the ethos of inquiry of the transformationalist approaches that is important: the task of interrogating and specifying forms, working out their historical relationships, entanglements, precedents, continuities and discontinuities.

\section{Drawing from Science \& Technology Studies (STS): Topologies of Race}

So far, we have argued that studies in the governmentality of migration need to engage more fully with the question of race, racialization and racism, and have encouraged researchers to consider the ways that race is being made, 
remade and unmade discursively and materially in the context of migration and border struggles. Here, we suggest that we can productively look at the recent debates in STS to find tools that are conceptually, methodologically and epistemologically compatible with a governmentality orientation to further this project. The concept of topology - which became influential in governmentality studies following Collier's (2009) seminal article and has been taken up in STS - is key here in bridging the two scholarships. Collier $(2009$, p. 80$)$ developed this concept through "a rough analogy to topology as a branch of mathematics concerned not exclusively with the geometrical properties of objects but with how spaces are organized, with the connectivity properties that arise from certain arrangements of elements, and with their transformation." He argues that by paying attention to the transformation and reconfiguration of heterogeneous bits and pieces, a topological approach is best "suited to analyzing the dynamic process through which existing elements, such as techniques, schemas of analysis, and material forms, are taken up and redeployed, and through which new combinations of elements are shaped" (Collier, 2009, p. 99). Although not often mobilized explicitly in the governmentality of migration and critical border scholarship, the concept of topology clearly belongs here. Indeed, this scholarship already produces accounts of borders as performed through an assemblage of dispersed practices, symbols, representations, architectural devices, check points, passports, visa, biometrics, data doubles and so on. Therefore, the recent work in STS that mobilizes the concept to study race can provide tools to conceptualize the production and performance of race in a way that is compatible with our theoretical framework, and help us start to better explain not only how race informs bordering but also how borders and race are mutually constitutive.

As we have seen, the argument that western societies have undergone a wholesale shift from biology-based to culture-based forms of race-making no longer holds up (M'Charek, Schramm \& Skinner, 2014a). After a period during which the objectification and reification of cultural differences seemed to have taken the central stage, today scholars talk of a "genetic reinscription of race" (Abu El-Haj, 2007, p. 283) - and in fact race has always mobilized both repertoires. And yet, despite this return of biology through genetics, we have difficulty accounting for the ways that race-making is also materially and biologically grounded for fear of contributing to its reification. Work in STS and CRT can help us in this task and provide us with tools to see how race-making is "intimately and inextricably linked to the matters, and not simply the meanings of race," as Rodríguez-Muñoz (2016, p. 216), playing with Winant's (2015) word, puts it. With STS scholars we can ask: what material and discursive bits and pieces play a role in race-making in historically- and context-specific situations? How might a focus on the technologies of population, policing, borders and identification enhance our understanding of race and racialization? And perhaps more precisely: what role do mobility and spatial arrangements play in producing race as a mode of 
knowing and organizing the world, and in racializing particular individuals and groups?

In his historical study of the production of race knowledges in colonial modernity, Roque (2014) looks at how the mobility of living human beings and artefacts such as skulls, blood, and biometrics became central in the production and the reification of something called race. He uses the concept of racial regimes of mobility to describe the paradox of how "the process of mobility of humans as scientific things [...] accompanied the sciences' pursuit of the immutable racial condition of humans" (Roque, 2014, p. 608). Race was produced, in part, through the circulation of humans as scientific things and their inscription into regimes of visibility in museums, curiosity shows, anthropological notes, medical cabinets and laboratories in Europe and elsewhere.

The image of a museum displaying human skulls will strike many readers as emblematic of the horrors of scientific racism and a frightful past that we have thankfully moved beyond. Yet do our technologies of population and border control not also rely upon circuits that put body parts, or traces and simulations thereof, in motion? We know, for instance, that the circulation of data doubles is central to migration and border governance (Lyon, 2008). Surveillance and governmentality scholars have studied these digital profiles as part of a surveillant assemblage that "operates by abstracting human bodies from their territorial settings and separating them into a series of discrete flows [that] are then reassembled into distinct 'data doubles' which can be scrutinized and targeted for intervention" (Haggerty \& Ericson, 2000, p. 606). They are assemblages of various data on nationality, patterns of consumptions, sites of travel, dietary preferences, countries of origin, biometric information, measurements, eye colours, marital status, and so on. They are at once tied to and detached from material bodies and social identity; they are at once absent and present, and they contribute to the way people are governed and therefore also to subject formation. Yet these systems have a very ambivalent and complex relationship to race. Unlike the technologies of migration control, which may have been quite explicit that their goal was to uphold a policy of White Australia or Chinese Exclusion, any kind of racial agenda is typically disavowed by political and security officials today. If challenged, they would probably respond that these databases and information systems are not about race but rather about managing problems of security, crime, illegal immigration, and terrorism. And yet, the burden of the exclusions and social hierarchies enacted by these programs and technologies fall very unevenly, and we should be careful not to conclude that this ambivalent relationship to race means that it is, in fact, not playing a fundamental role (see Pugliese, 2010; Browne, 2015). We need to find ways to map out its presence.

It is precisely this ambivalence that forms the entry point of M'Charek, Schramm and Skinner's (2014b) work. "In the European context, race is shadowy and seldom expressed openly in language," they observe, leading 
them to "examine technologies that seem indifferent to racial differences and show how in specific practices they contribute to the enactment of race" (M'Charek, Schramm \& Skinner, 2014b, p. 471). Their key theoretical move is to insist on the utility of topology as a concept and imaginary for theorizing race amidst a focus on technologies of government. The idea of a topology of race is itself not new. Some time ago, Lee (1994, p. 758) argued that "we can never predict whether a practice will be racist or antiracist. Instead, we must examine the practice's social situation and effects" in order to make sense of "the constantly changing topology of race and racism." But topology has acquired a recent centrality in scholarship where it is now embedded in the study of technologies of power and the recombinatory properties of assemblages (Collier, 2009; see also Robinson, 1999). It is this line of analysis that we argue can help us produce accounts of race-in-the-making through borderwork.

In M'Charek, Schramm and Skinner's (2014b, p. 471) version, topology attends to "the distributed nature of race," allowing race to be understood as a "temporal and spatial relation that cannot be reduced to one single entity (skin tone, DNA, religion, culture, nationality) or traced through a single, linear historical process." They give the example of a university that might want to collect data on the countries of origin of its students. In many contexts, knowing that a student is of Moroccan descent is not necessarily race-related. After all, such data might be sought for marketing purposes. But when the database is linked to crime statistics, and when the student is studying in the Netherlands today, this "classification might become a racial category suggesting the tendency of Moroccans to commit crime" (M'Charek, Schramm \& Skinner, 2014b, p. 472). For a topological approach, the level of analysis becomes not the individual, the group, or ideologies, but the sociotechnical assemblage. It is all about following the connections, the relations, the couplings and uncouplings by which things that are otherwise distant in space and time, and not intrinsically related, get brought into a relationship.

We argue that a topological approach has much to offer to the attempt to figure race and racism within the governmentality of migration, borders and populations. Robinson (1999, p. 60) argues that topologies employ analyses which move "more through continuous folding and involution at critical points" whereas chronologies utilize a linear evolution, from segment to segment. Hence, topologies compensate and challenge any residual chronological tendencies that might inhere in the transformationalist framing that we already discussed. But in favouring a mathematical metaphor, we should not gloss over struggles and conflicts, we should not imagine a smooth space. We insist that the notion of topology should be broadened to encompass the ways in which race is named and critiqued within processes of contestation and struggle. Echoing the point we made in our earlier discussion of racialization as generic process, here too more consideration needs to be given to the role that contestation plays in the production of race. 
The point is best made through another example, this time about contested meaning of the unequal distribution of traffic stops among various groups in the Canadian capital. Our point in highlighting this case is to show how a topological approach can engage with contestation. In 2016, an expert report was published showing that "in Ottawa, Middle Easterner and Black groups, irrespective of their sex and age, are the two race groups with disproportionately high incidences of traffic stop," a situation even worse for men 16 to 24 years old (Foster, Jaccobs \& Siu 2016, pp. 3-4). Data for the report came from analysis by a research team from York University of over 80,000 traffic stops. Like most Canadian forces, Ottawa police does not collect data on the race or ethnicity of those stopped. In the absence of such data, police could claim they do not practice racial profiling. But in this case, the police agreed to collect and share such data as part of a settlement involving an earlier human rights case brought against them. While the researchers were careful to state that their statistical report could only prove the existence of disproportionality in stops, not of racial profiling by officers, the evidence did seem to point to the reality of racial profiling. Once the report was made public, a debate about racial profiling ensued, with public consultations and discussion as to what steps, if any, needed to be taken.

Race is constructed in a particular way here - as racial profiling - amidst a very heterogeneous ensemble of relationships, technologies, persons and things, which include traffic stops, police databases, criminologists, race data, high-crime neighbourhoods, civil society groups, human rights agencies, and driving. But what it also suggests - the value-added of this example - is that race only emerges in this specific form here because of struggles and contestations. Had actors not mobilized in the first place, the Ontario Human Rights Commission would probably never have pressured the police to collect so-called race data. Moreover, it is not as though the report establishes a consensus so much as a "hybrid forum" in which disagreements circulate (Callon, Lascoumbes \& Barthe, 2009, p. 139). Even for the police chief, it seems that it was and wasn't about racial profiling. Indeed, in the media, he stressed that the report did not prove racial profiling was being practised by his force. But later, at a police-organized event to present the results and attended mostly by Black residents, the public was getting annoyed at the researchers insisting that methodologically speaking, their research may suggest the possibility of racial profiling but simply could not prove its existence. The chief of police responded by acknowledging publicly that there appears to be a problem of racial profiling in the Ottawa police like in the rest of society. Race, in the form of racial profiling, appears here not as a matter of fact, but following Latour (2005, p. 19), as a hotly contested "matter-of-concern."

Let us conclude this discussion of topologies of race by noting that there is a methodological lesson here. Many observers would see racial profiling as evidence of racist discrimination. It would appear as a somewhat self-evident phenomenon, a social expression of something more deeply seated, such as 
institutional racism. A topological approach turns this assumption on its head. Instead, it treats racial profiling as an event, a peculiar object whose emergence we need to trace quite empirically across various sites and incidents. The point would be that, as with Hacking's (1991) genealogy of child abuse, racial violence has an extremely long history. But racial profiling is a relatively new object whose contours, formation and conditions of possibility we can examine in all their singularity. And recognizing the role that oppositional groups and forces play in all this is crucial. When race is an absent-presence, the temptation is for the scholar to appear as the sharp-eyed observer who discerns its presence when others do not. But when we attend to the way social actors mobilize and name race themselves, then we are able to side-step this problem and instead deepen our understanding of race as something made and unmade from all sides and directions (including by scholars).

\section{Conclusion}

In this article, we have argued that the scholarship on the governmentality of migration and borders has been insufficiently attentive to questions of race and racism. At the same time, we have recognized important work that has engaged with these questions. To better appreciate the nature of that work and to advance further research on governmentality and race, we proposed a non-exhaustive typology of three different framings of race and racism already present in this scholarship. We then turned to a discussion of some very recent work that, drawing from STS, investigates race in terms of topologies. A topological approach captures folds, reversals and recombinations in a way that might be missed by a more linear narrative. It is therefore well suited to capture "both the surprises and the constancies of race and also why newness comes temporally freighted" (Amin 2010, p. 5, cited in Venn 2011, p. 104). And because topology emphasizes that the construction of race happens through the connections and disconnections forged between near and far, old and new, it also offers us a distributed account of race, one in which no particular property or element is essential, but any can become active markers of difference. This focus on distribution and connection lends topologies well to the analysis of race as absent-presence.

Yet we do not intend to set up a hierarchy here. All these framings have their uses. It is better to think of them as tools that might be used in conjunction, as and where appropriate, rather than self-contained theories. For example, to study topologies we require, as M'Charek, Schramm and Skinner (2014b) note, detailed and contextualized case studies. But the danger of such a focus is to lose sight of much broader patterns of change, the kind which writing on racialization and transformation have captured well. One of the little noted features of what Foucault does when he writes genealogies is that he brings a polytemporal and multiscalar sensibility to the 
understanding of power. Like a film-maker, he zooms in and out. For example, in his lectures on governmentality, he combines an appreciation for changes in pastoral power on the scale of millennia with a fine-grained analysis of neo-liberalism unfolding on the scale of decades. It is just this kind of sensibility which we want to encourage in future research at the interface of the governmentality of race, migration and borders. Bringing a focus on topology into the mix of tools can be a useful contribution to that end.

\section{Acknowledgments}

An earlier version of this paper was presented at the 2017 European International Studies Association Conference, and at a monthly seminar that we co-host in Ottawa. We thank our discussant, Vivienne Jabri, for her excellent comments, and the audience for their questions.

\section{References}

Abu El-Haj, N. (2007). The genetic reinscription of race. Annual Review of Anthropology, 36(1), 283-300.

Ahmed, S. (2003). The politics of fear in the making of worlds. Qualitative Studies in Education, 16(3), 377-398.

Amin, A. (2010). The remainders of race. Theory, Culture \& Society, 27(1), 1-23.

Amin-Khan, T. (2012). New orientalism, securitisation and the western media's incendiary racism. Third World Quarterly, 33(9), 1595-1610.

Balibar, É. (1991). Is there a "neo-racism"? In É. Balibar \& I. Wallerstein (Eds.), Race, nation, class: Ambiguous identities (pp. 17-28). London: Verso.

Ball, K., Haggerty, K. D., \& Lyon, D. (Eds.). (2012). Routledge handbook of surveillance studies. London: Routledge.

Barot, R., \& Bird, J. (2001). Racialization: The genealogy and critique of a concept. Ethnic and Racial Studies, 24(4), 601-618.

Basham, V. M., \& Vaughan-Williams, N. (2013). Gender, race and border security practices: A profane reading of "muscular liberalism." British Journal of Politics and International Relations, 15(4), 509-527.

Bigo, D. (2002). Security and immigration: Toward a critique of the governmentality of unease. Alternatives, 27(1), 63-92.

Bourbeau, P. (2011). The securitization of migration: A study of movement and order. London: Routledge.

Browne, S. (2015). Dark matters: On the surveillance of Blackness. Durham, NC: Duke University Press.

Browne, S. (2012). Race and surveillance. In K. Ball, K. D. Haggerty \& D. Lyon (Eds.), Routledge handbook of surveillance studies (pp. 72-79). London: Routledge.

Browne, S. (2010). Digital epidermalization: Race, identity and biometrics. Critical Sociology, $36(1), 131-150$.

Callon, M., Lascoumbes, P., \& Barthe, Y. (2009). Acting in an uncertain world : An essay on technical democracy. Cambridge, MA: MIT Press.

Collier, S.J. (2009). Topologies of power: Foucault's analysis of political governmentality beyond 'governmentality'. Theory, Culture \& Society, 26(6), 78-108.

Dean, M. (1999). Governmentality: Power and rule in modern society. London: Sage. 
De Genova, N. (2016). The European question: Migration, race, and postcoloniality in Europe. Social Text, 24(3), 75-102.

De Genova, N., Mezzadra, S., \& Pickles, J. (2015). New keywords: Migration and borders. Cultural Studies, 29(1), 55-87.

Dillon, M., \& Lobo-Guerrero, L. (2008). Biopolitics of security in the $21^{\text {st }}$ century: An introduction. Review of International Studies, 34(2), 265-292.

Duffield, M. (2006). Racism, migration and development: The foundations of planetary order. Progress in Development Studies, 6(1), 68-79.

Fassin, D. (2011). Policing borders, producing boundaries: The governmentality of immigration in dark times. Annual Review of Anthropology, 40, 213-226.

Foster, L., Jacobs, L., \& Siu, B. (2016). Race data and traffic stops in Ottawa, 2013-15. Report submitted to Ottawa Police Services Board \& Ottawa Police Services. Retrieved from https://www.ottawapolice.ca/en/about-us/resources/.TSRDCP_York_Research_Report.pdf

Foucault, M. (2007). Security, territory, population: Lectures at the Collège de France, 19771978. New York: Palgrave Macmillan.

Foucault, M. (2003). Society must be defended: Lectures at the Collège de France, 1975-1976. New York: Picador.

Geiger, M., \& Pécoud, A. (Eds.). (2013). Disciplining the transnational mobility of people. Houndmills, UK: Palgrave Macmillan.

Gilroy, P. (2001). Against race: Imagining political culture beyond the color line. Cambridge, MA: Harvard University Press.

Goldberg, D. T. (2009). The threat of race: Reflections on racial neoliberalism. Oxford: WileyBlackwell.

Gruffydd Jones, B. (2008). Race in the ontology of international order. Political Studies, 56(4), 907-927.

Hacking, I. (1991). The making and molding of child abuse. Critical Inquiry, 17(2), 253-288.

Haggerty, K. D., \& Ericson, R. V. (2000). The surveillant assemblage. British Journal of Sociology, 51(4), 605-622.

Hall, S. (1996). The after-life of Frantz Fanon: Why Fanon? Why now? Why Black Skin, White Masks? In A. Read (Ed.), The fact of Blackness: Frantz Fanon and visual representation (pp.12-37). London: Institute of Contemporary Arts.

Hansen, P., \& Jonsson, S. (2011). Demographic colonialism: EU-African migration management and the legacy of Eurafrica. Globalizations, 8(3), 261-276.

Hindess, B. (2002). Neoliberal citizenship. Citizenship Studies, 6(2), 127-143.

Huysmans, J. (2006). The politics of insecurity: Fear, migration, and asylum in the EU. London: Routledge.

Ibrahim, M. (2005). The securitization of migration: A racial discourse. International Migration, 43(5), 163-187.

Inda, J.X . (2014). Racial prescriptions: Pharmaceuticals, difference, and the politics of life. Farnham, UK: Ashgate.

Jabri, V. (2007). Michel Foucault's analytics of war: The social, the imperial, and the racial. International Political Sociology, 1(1), 67-81.

Kobayashi, A., \& Peake, L. (2000). Racism out of place: Thoughts on whiteness and an antiracist geography in the new millennium. Annals of the Association of American Geographers, 90(2), 392-403.

Korvensyrjä, A. (2017). The Valetta process and the Westphalian imaginary of migration research. Movements, 3(1), 191-204.

Latour, B. (2005). From realpolitik to dingpolitik, or how to make things public. In B. Latour \& P. Weibel (Eds.), Making things public: Atmospheres of democracy (pp. 14-41).

Cambridge, MA: MIT Press.

Lee, J. C-S. (1994). Navigating the topology of race. Stanford Law Review, 46(3), 747-780.

Lyon, D. (2008). Filtering flows, friends, and foes: Global surveillance. In M. B. Salter (Ed.), Politics at the airport (pp. 29-49). Minneapolis, MN: University of Minnesota Press.

M'charek, A., Schramm, K., \& Skinner, D. (2014a). Technologies of belonging: The absent presence of race in Europe. Science, Technology \& Human Values, 39(4), 459-467. 
M'charek, A., Schramm, K., \& Skinner, D. (2014b). Topologies of race: Doing territory, population and identity in Europe. Science, Technology \& Human Values, 39(4), 468-487.

Mezzadra, S., \& Rahola, F. (2006). The postcolonial condition: A few notes on the quality of historical time in the global present. Postcolonial Text, 2(1), n.p. Retrieved from http://postcolonial.org/index.php/pct/article/view/393/819

Mezzadra, S., Reid, J., \& Samaddar, R. (2013). Introduction: Reading Foucault in the postcolonial present. In S. Mezzadra, J. Reid \& R. Samaddar (Eds.), The biopolitics of development: Reading Michel Foucault in the postcolonial present (pp. 1-14). New York: Springer.

Moffette, D., \& Vadasaria, S. (2016). Uninhibited violence: Race and the securitization of immigration. Critical Studies on Security, 4(3), 393-413.

Muller, B. (2009). Borders, risks, exclusions. Studies in Social Justice, 3(1), 67-78.

Muri, K., \& Solomos, J. (2004). Racialization: Studies in theory and practice. Oxford: Oxford University Press.

O’Malley, P., Weir, L., \& Shearing, C. (1997). Governmentality, criticism, politics. Economy \& Society, 26(4), 501-517.

Pugliese, J. (2010). Biometrics: Bodies, Technologies, Biopolitics. New York: Routledge.

Razack, S. (2004). Imperilled Muslim women, dangerous Muslim men and civilised Europeans: Legal and social responses to forced marriages. Feminist Legal Studies, 12(2), 129-174.

Robinson, K. (1999). Thought of the outside: The Foucault/Deleuze conjunction. Philosophy Today, 43(1), 57-72.

Rodríguez-Muñiz, M. (2016). Bridgework: STS, sociology, and the "dark matters" of race. Engaging Science, Technology \& Society, 2, 214-226.

Roque, R. (2014). Race and the mobility of humans as things. Science, Technology \& Human Values, 39(4), 607-617.

Rose, N. (1999). Powers of freedom: Reframing political thought. Cambridge: Cambridge University Press.

Rose, N., \& Novas, C. (2005). Biological citizenship. In S. J. Collier \& A. Ong (Eds.), Global assemblage: Technology, politics and ethics as anthropological problems (pp. 439-463). Malden, MA: Blackwell.

Rumford, C. (2006). Theorizing borders. European Journal of Social Theory, 9(2), 155-169.

Sabaratnam, M. (2011). IR in dialogue... But can we change the subjects? A typology of decolonising strategies for the study of world politics. Millennium: Journal of International Studies, 39(3), 781-803.

Sa'di, A. H. (2012). Colonialism and surveillance. In K. Ball, K. D. Haggerty \& D. Lyon (Eds.), Routledge handbook of surveillance studies (pp. 151-158). London: Routledge.

Scheel, S. (2013a). Autonomy of migration despite its securitization? Facing the terms and conditions of biometric rebordering. Millennium: Journal of International Studies, 41(3), 575-600.

Scheel, S. (2013b). Studying embodied encounters: Autonomy of migration beyond its romanticization. Postcolonial Studies, 16(3), 279-288.

Schinkel, W., \& Van Houdt, F. (2010). The double helix of cultural assimilationism and neoliberalism: Citizenship in contemporary governmentality. British Journal of Sociology, 61(4), 696-715.

Sedgwick, E. K. (1993). The epistemology of the closet. In H. Abelove, M. A. Barale \& D. M. Halperin (Eds.), The lesbian and gay studies reader (pp. 45-61). London: Routledge.

Sharma, N. (2009). Escape artists: Migrants and the politics of naming. Subjectivity, 29(1), 467476.

Taguieff, P-A. (1986). L'identité nationale saisie par les logiques de racisation. Aspects, figures et problèmes du racisme différentialiste. Mots, 12, 91-128.

Turner, J. (2015). The family migration visa in the history of marriage restrictions: Postcolonial relations and the UK border. British Journal of Politics and International Relations, 17, 623-643.

Venn, C. (2011). Introduction - Reflections on "the remainders of race": Culture, nature or a political economy of race? Theory, Culture \& Society, 28(1), 103-111. 
Vitalis, R. (2015). White world order, Black power politics: The birth of American international relations. Ithaca, NY: Cornell University Press.

Vucetic, S. (2015). Against race taboos: The global colour line in philosophical discourse. In A. Anievas, N. Manchanda \& R. Shilliam (Eds.), Race and racism in international relations: Confronting the global colour line (pp. 98-114). London: Routledge.

Vukov, T. (2016). Target practice: The algorithmics and biopolitics of race in emerging smart border practices and technologies. Transfers, 6(1), 80-97.

Wade, P. (2010). The presence and absence of race. Patterns of Prejudice, 44(1), 43-60.

Walters, W. (2015). Reflections on migration and governmentality. Movements, 1(1), 1-25. Retrieved from http://movements-journal.org/issues/01.grenzregime/04.walters-migration.governmentality.pdf

Walters, W. (2012). Governmentality: Critical encounters. London: Routledge.

Winant, H. (2015). The dark matter: Race and racism in the $21^{\text {st }}$ century. Critical Sociology, 41(2), 313-324. 